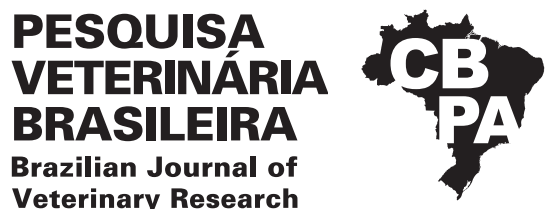

Pesq. Vet. Bras. 40(4):261-265, April 2020 DOI: $10.1590 / 1678-5150-P V B-6318$

Original Article narv Research

ISSN 0100-736X (Print) Livestock Diseases

ISSN 1678-5150 (Online)

\title{
Serological survey of bluetongue virus in sheep from Minas Gerais ${ }^{1}$
}

\author{
Daniel A. Biihrer ${ }^{2}$ (D) , Adriana S. Albuquerque ${ }^{3}$, Adriana H.C.N. Romaldini ${ }^{4}$, \\ Edviges M. Pituco ${ }^{4}$, Ana Carolina D. Matos ${ }^{5}$, Zelia I.P. Lobato ${ }^{5}$, \\ Mary S. Varaschin ${ }^{3}$ and Djeison L. Raymundo ${ }^{3 *}$ (D)
}

\begin{abstract}
Biihrer D.A., Albuquerque A.S., Romaldini A.H.C.N., Pituco E.M., Matos A.C.D., Lobato Z.I.P., Varaschin M.S. \& Raymundo D.L. 2020. Serological survey of bluetongue virus in sheep from Minas Gerais. Pesquisa Veterinária Brasileira 40(4):261-265. Departamento de Medicina Veterinária, Universidade Federal de Lavras, Campus Histórico, Cx. Postal 3037, Av. Doutor Sylvio Menicucci 1001, Lavras, MG 37200-000, Brazil. E-mail: djeison.raymundo@dmv.ufla.br

Bluetongue is an infectious, non-contagious disease that affects domestic and wild ruminants, caused by a virus from the Orbivirus genus, Reoviridae family, transmitted by arthropod vectors of the Culicoides genus. This paper aims to be the first serological survey of bluetongue in sheep from the Meso-regions of Campo das Vertentes and South and Southeast of Minas Gerais. Samples were collected from sheep from different properties. The serum samples were submitted to Agar Gel Immunodiffusion (AGID) and competitive Enzyme-Linked Immunosorbent Assay (cELISA). 303 serum samples were submitted to AGID and cELISA. In these samples, $164(54.13 \%)$ were positive in the AGID technique, and $171(56.44 \%)$ positive in the cELISA technique, with an almost perfect agreement between the techniques (kappa index $=0.887$ ). In all visited properties, positive animals have been found in the herd. Animals acquired from properties of the studied mesoregions were more likely to be positive in IDGA and cELISA tests than animals acquired from properties in other regions of Brazil $(p<0.001)$. These results suggest that bluetongue virus (BTV) is widespread in the mesoregions of Campo das Vertentes and South and Southeast of Minas Gerais.
\end{abstract}

INDEX TERMS: Serological survey, bluetongue virus, sheep, Minas Gerais, Brazil, Orbivirus, diagnosis, serology, sheep farming, ovine.

RESUMO.- [Inquérito sorológico do vírus da língua azul em ovinos de Minas Gerais.] A língua azul (LA) é uma doença infecciosa, não contagiosa, que acomete ruminantes domésticos e silvestres, causada por um vírus do gênero Orbivirus da família Reoviridae, transmitida por vetores artrópodes do gênero Culicoides. 0 presente estudo representa o primeiro trabalho a realizar um inquérito sorológico da língua azul em rebanhos ovinos nas Mesorregiões de Campo das Vertentes e Sul e Sudoeste de Minas Gerais. Foram coletadas amostras de soro de ovinos de diferentes propriedades. As amostras de soro foram submetidas aos testes de imunodifusão em gel de ágar (IDGA) e ensaio de imunoadsorção enzimática

\footnotetext{
${ }^{1}$ Received on May 31, 2019.

Accepted for publication on July 10, 2019.

${ }^{2}$ Departamento de Patologia, Faculdade de Medicina Veterinária e Zootecnia (FMVZ), Universidade de São Paulo (USP), Av. Prof. Orlando Marques de Paiva 87, Butantã, São Paulo, SP 05508-010, Brazil.

${ }^{3}$ Departamento de Medicina Veterinária (DMV), Universidade Federal de Lavras (UFLA), Campus Histórico, Cx. Postal 3037, Av. Doutor Sylvio
}

por competição (cELISA). Ao todo 303 amostras de soro foram submetidas ao IDGA e cELISA. Dessas amostras, 164 $(54,13 \%)$ foram positivas na técnica de IDGA e 171 (56,44\%) positivas na técnica de cELISA, havendo concordância quase perfeita entre as técnicas (índice kappa $=0,887$ ). Em todas as propriedades visitadas, foram encontrados animais positivos no rebanho. Animais adquiridos de propriedades das Mesorregiões estudadas, tiveram mais chances de serem positivos nos testes de IDGA e cELISA do que animais adquiridos de propriedades de outras Regiões do Brasil $(\mathrm{p}<0,001)$. Esses resultados sugerem que o vírus da língua

\footnotetext{
Menicucci 1001, Lavras, MG 37200-000, Brazil. *Corresponding author: djeison.raymundo@dmv.ufla.br

${ }^{4}$ Laboratório de Viroses de Bovinos, Instituto Biológico de São Paulo, Av. Conselheiro Rodrigues Alves 1252, Vila Mariana, São Paulo, SP 04014-002, Brazil.

${ }^{5}$ Departamento de Medicina Veterinária Preventiva, Escola de Veterinária, Universidade Federal de Minas Gerais (UFMG), Campus Pampulha, Av. Pres. Antônio Carlos 6627, São Luiz, Belo Horizonte, MG 31270-901 Brazil.
} 
azul encontra-se disseminado em ovinos nas Mesorregiões de Campo das Vertentes e Sul e Sudoeste de Minas Gerais.

TERMOS DE INDEXAÇÃO: Inquérito sorológico, vírus da língua azul, ovinos, Minas Gerais, Brasil, Orbivirus, diagnóstico, sorologia, ovinocultura.

\section{INTRODUCTION}

The bluetongue (BT) disease is caused by a virus of the genus Orbivirus of the family Reoviridae, transmitted by arthropods of the genus Culicoides, especially in the hot and humid times of the year, which favor the proliferation of these vectors (Maclachlan 2011). Currently, 26 serotypes of the bluetongue virus (BTV) are recognized worldwide (OIE 2018), grouped according to their serological reactivity. BTV is capable of infecting several domestic and wild ruminants, including sheep, goats, cattle, buffalo, and deer. The clinical form of the disease is most commonly seen in sheep and deer (Sánchez-Cordón et al. 2013, Ruiz-Fons et al. 2014).

Several serological surveys carried out in cattle, sheep, and goats in different states of Brazil have shown that the Southeast (Lobato et al. 2001, Konrad et al. 2003), Midwest (Tomich et al. 2009, Dorneles et al. 2012) and North regions (Abreu 1982) have a high number of seropositive animals. The South (Costa et al. 2006) and Northeast (Melo et al. 2000, Silva 2002, Souza et al. 2010) regions have meager seroprevalence rates. The low rates of seropositivity observed in the Northeast and South Regions may be associated with the unfavorable climate of the semi-arid region and more severe winters in these two regions, which would make it difficult to multiply or maintain the vector (Melo et al. 2000, Costa et al. 2006).

From the diagnosis of BTV, serotype 4, in clinical disease in a sheep herd in the Mesoregion of Campo das Vertentes in Minas Gerais (Lima et al. 2016), it was noticed that the virus is present in sheep in the state. However, serological data on the virus presence in the Mesoregions of Campo das Vertentes and South and Southwest of Minas Gerais were not known until then. This study aimed to be the first serological survey of the BTV in these mesoregions.

\section{MATERIALS AND METHODS}

This work is duly registered with the Ethics Committee on the Use of Animals of the "Universidade Federal de Lavras" (CEUA-UFLA) under number 023/2013.

Sample collection locations. Serum collection was performed on sheep farms in the Mesoregions of Campo das Vertentes and South and Southwest of Minas Gerais during the period from August 2015 to October 2016. A preliminary survey with the "Instituto Mineiro de Agropecuária" (IMA) highlighted 22 properties that develop sheep farming in the regions close to the municipality of Lavras, with a herd that varies from 10 to 1000 sheep. The properties with the highest number of adult animals were selected for the collection of serum samples. From the contact with the breeders, the collection was carried out in eight properties in the municipalities of Santo Antônio do Amparo, São João Del Rey, Nazareno, Ritápolis, Cambuquira, Soledade de Minas and two properties in Nepomuceno. At each property, blood samples were collected from at least 30\% of the herd or the entire herd when it was less than 50 animals, in addition to information about the breeding system, access to veterinary assistance, and the animals' place of origin.
Search for antibodies against BTV in serum samples. Sample collection was performed after the physical containment of the animals, with blood drawn from the jugular vein in blood collection tubes without anticoagulants. The samples were transported refrigerated to the "Universidade Federal de Lavras" where they were centrifuged. The serum was stored, in duplicate, in $1.5 \mathrm{ml}$ microtubes, and frozen at $-20^{\circ} \mathrm{C}$ until the exams were performed.

The serum samples of each animal were sent to the Animal Virology Research Laboratory of the "Departmento de Medicina Veterinária Preventiva" at the "Universidade Federal de Minas Gerais" (UFMG) and to the Bovine Virus Laboratory of the "Instituto Biológico de São Paulo". Then, it was performed, respectively, the tests of IDGA and cELISA, for the detection of antibodies against BTV.

cELISA. To perform cELISA, the commercial Bluetongue Virus Antibody Test Kit VMRD ${ }^{\circledR}$ Kit was used, following the manufacturer's instructions. For each sample, $25 \mu \mathrm{L}$ of the serum to be tested was used. The samples, positive (present in the kit), and negative controls were incubated at room temperature for 15 minutes. Then, $25 \mu \mathrm{L}$ of the antibody-peroxidase conjugate was added to each well. The plate was incubated for another 15 minutes at room temperature. After three washing steps, $50 \mu \mathrm{L}$ of the substrate solution was added for a 10-minute incubation period. Then $50 \mu \mathrm{L}$ of stop solution was added, and the plates were read in an ELISA reader model Thermo Labsystem Multiskan Ascent with 620nm filter to obtain the optical density (OD) values. The samples were considered positive when their OD values corresponded to less than $50 \%$ of the average OD values of the negative controls, using two standard deviations (two negative and two positive controls).

IDGA. To perform the IDGA technique, $0.85 \%$ sodium chloride $(\mathrm{NaCl})$ solution and agarose at a final concentration of $0.9 \%$ in deionized water, deposited on circular acrylic plates, were used. Seven rosettes with seven holes each were drilled on each plate. The antigen was placed in the central well and the positive control serum in three other alternating wells in the amount of $30 \mu \mathrm{L}$ in each well. In the remaining wells, $30 \mu \mathrm{L}$ of the serum samples to be tested were placed. The plates remained in a humid chamber with $0.3 \%$ magnesium sulfate for 48 hours at room temperature. Then, the plates were observed with the aid of indirect light in a dark field. The antigen and positive control serum came from the UFMG Veterinary School.

Statistical analysis. Statistical analyzes were performed using the Epi-info ${ }^{\mathrm{TM}} 7$ program. The agreement between the cELISA and IDGA techniques was determined using the kappa coefficient (Thrusfield 2004). The Chi-square test was used to associate the results of the serology of sheep with the origin of animals (Thrusfield 2004).

\section{RESULTS AND DISCUSSION}

Of the 303 sheep serum samples analyzed, 171 (56.4\%) were positive in cELISA (Table 1) and 164 (54.1\%) in IDGA (Table 2). The results obtained from serological tests show that all properties were positive - the virus is not only present but also has already circulated in all properties visited in this study; this shows how the virus is spread in the regions close to the municipality of Lavras.

This work was the first serological survey carried out in the Mesoregions of Campo das Vertentes and South and Southwest of Minas Gerais. Other studies carried out in the state of Minas Gerais (Lobato et al. 2001, Laender 2002), also show that the Blue Tongue virus can be found in other Mesoregions of the state. The positivity values found in this study $(56.44 \%$ and $54.13 \%)$ are similar to those observed in 
other studies carried out in Minas Gerais, in the Mesoregions of Norte de Minas, Jequitinhonha and Vale do Mucuri, $58.6 \%$ by Laender (2002) and 65\% by Lobato and collaborators (2001).

The wide distribution of this virus in the state is a characteristic of the Southeast region of Brazil. In this region, the climate and the sparse rains throughout the year, guarantee adequate humidity and temperature for the proliferation of the vector mosquito (Laender 2002). The large cattle herd in the region may be responsible for the maintenance of the virus since this species works as a reservoir of the virus. Studies in the north and northeast regions of Minas Gerais show a high prevalence of antibodies against BTV in cattle (Konrad et al. 2003). However, there are no serological surveys for BTV in this species in the regions studied in this work. The value of the kappa index between the results of the techniques of IDGA and cELISA (Table 3) demonstrated an almost perfect agreement between the techniques (Thrusfield 2004). This value was higher than other values found in the literature, which showed moderate (Venditti 2009) and substantial (Nogueira 2008) agreement. Although the OIE has prescribed the IDGA technique since 1982, it recommends the use of cELISA to confirm positive results to exclude possible cross-reactions with other Orbiviruses, in addition to being a more sensitive technique (OIE 2018). However, the agreement value shows that the AGID technique can still be used as an important method of seroepidemiological surveillance.

The eighth property had the lowest number of positive animals (22.31\%). The large number of animals collected was

Table 1. Distribution of the number and percentage of reactive sheep in the cELISA test to detect antibodies against BTV, according to the properties of Campos das Vertentes Mesoregions and South and Southwest of Minas Gerais

\begin{tabular}{|c|c|c|c|c|c|}
\hline \multirow{2}{*}{ Properties } & \multirow{2}{*}{$\begin{array}{l}\text { No. of analyzed } \\
\text { samples }\end{array}$} & \multirow{2}{*}{$\begin{array}{l}\text { Total adult sheep by } \\
\text { property }\end{array}$} & \multicolumn{2}{|c|}{ cELISA results } & \multirow{2}{*}{$\%$ of positives } \\
\hline & & & Positive & Negative & \\
\hline $\mathrm{P} 1$ & 29 & 91 & 18 & 11 & $62.07 \%$ \\
\hline P3 & 16 & 16 & 16 & 0 & $100.00 \%$ \\
\hline P4 & 24 & 79 & 17 & 7 & $70.83 \%$ \\
\hline P6 & 16 & 16 & 12 & 4 & $75.00 \%$ \\
\hline P7 & 32 & 32 & 30 & 2 & $93.75 \%$ \\
\hline P8 & 130 & 400 & 29 & 101 & $22.31 \%$ \\
\hline Total & 303 & 780 & 171 & 132 & $56.44 \%$ \\
\hline
\end{tabular}

Table 2. Distribution of the number and percentage of reactive sheep in the IDGA exam for detection of antibodies against BTV, according to the properties of Campos das Vertentes Mesoregions and South and Southwest of Minas Gerais

\begin{tabular}{|c|c|c|c|c|c|}
\hline \multirow{2}{*}{ Properties } & \multirow{2}{*}{$\begin{array}{l}\text { No. of analyzed } \\
\text { samples }\end{array}$} & \multirow{2}{*}{$\begin{array}{l}\text { Total adult sheep by } \\
\text { property }\end{array}$} & \multicolumn{2}{|c|}{ IDGA results } & \multirow{2}{*}{$\%$ of positives } \\
\hline & & & Positive & Negative & \\
\hline $\mathrm{P} 1$ & 29 & 91 & 16 & 13 & $55.17 \%$ \\
\hline P3 & 16 & 16 & 16 & 0 & $100.00 \%$ \\
\hline $\mathrm{P} 4$ & 24 & 79 & 15 & 9 & $62.50 \%$ \\
\hline P6 & 16 & 16 & 12 & 4 & $75.00 \%$ \\
\hline P7 & 32 & 32 & 28 & 4 & $87.50 \%$ \\
\hline P8 & 130 & 400 & 29 & 101 & $22.31 \%$ \\
\hline Total & 303 & 780 & 164 & 139 & $54.13 \%$ \\
\hline
\end{tabular}

Table 3. Comparison of the results obtained between the cELISA and IDGA techniques against BTV of 303 sheep serum collected in the Campos das Vertentes Mesoregions and South and Southwest of Minas Gerais

\begin{tabular}{|c|c|c|c|c|c|c|}
\hline & IDGA positive & IDGA negative & Total & Kappa & IC 95\% & $\mathrm{P}$ \\
\hline cELISA positive & 159 & 12 & 171 & & & \\
\hline cELISA negative & 5 & 127 & 132 & 0.887 & $0.774 ; 0.999$ & $<0.001$ \\
\hline Total & 164 & 139 & 303 & & & \\
\hline
\end{tabular}


Table 4. Positive and negative sheep using the cELISA and IDGA techniques, considering the region of origin of 303 sheep collected in the Campo das Vertentes Mesoregions and South and Southwest of Minas Gerais

\begin{tabular}{|c|c|c|c|c|c|c|c|}
\hline & \multirow{2}{*}{ Origin of the sheep } & \multicolumn{2}{|c|}{ Serological result } & \multirow{2}{*}{ Total } & \multirow{2}{*}{ Odds ratio } & \multirow{2}{*}{ CI (95\%) } & \multirow{2}{*}{ p value } \\
\hline & & Positive & Negative & & & & \\
\hline \multirow{2}{*}{ cELISA } & Own region & 114 & 27 & 141 & \multirow{2}{*}{7.8} & \multirow{2}{*}{$4.58 ; 13.2$} & \multirow{2}{*}{$<0.001$} \\
\hline & Other regions & 57 & 105 & 162 & & & \\
\hline \multirow{2}{*}{ IDGA } & Own region & 107 & 34 & 141 & \multirow{2}{*}{5.8} & \multirow{2}{*}{$3.51 ; 9.59$} & \multirow{2}{*}{$<0.001$} \\
\hline & Other regions & 57 & 105 & 162 & & & \\
\hline
\end{tabular}

* Chi-square test.

due to the large herd of this property, which had sheep raised intensively for milk production. This creation had a more advanced degree of technification, hygiene, and veterinary assistance for the sheep, in addition to fans for air circulation in the animals' confinement area. Better hygiene at the animals' location was associated with a protective factor against BT (Alves et al. 2009). It may be related to the smaller number of positive animals on this property.

Regarding the origin of the animals purchased on each property, 141 animals (46.5\%) came from other producers in the region itself (Mesoregions of Campo das Vertentes and South and Southwest of Minas Gerais). In comparison, 162 animals (53.5\%) were acquired from the Regions of Paraná, Santa Catarina, and Goiás. Table 4 compares these data with the animals' positivity in the IDGA and cELISA tests.

As noted, in both tests, there was a significance for animals from the region itself having more chances of being positive than animals acquired from other regions. This fact may be related to the lack of control in the transit of these animals between the properties. Much of the obtaining of new animals takes place among the region's producers, without any type of veterinary supervision or serological surveillance. Besides, there are a large number of positive animals in the Mesoregions of Campo das Vertentes and South and Southwest of Minas Gerais. The property with the lowest number of positive animals (P8) frequently acquires its animals from Santa Catarina, Southern Region of Brazil, which, according to previous serological surveys, has low animal positivity (Melo et al. 2000, Costa et al. 2006).

\section{CONCLUSIONS}

Bluetongue virus (BTV) circulates in the sheep herd in the Mesoregions of Campo das Vertentes and South and Southwest of Minas Gerais state.

All of the properties studied in the region show positive animals for antibodies against BTV, and most of these properties demonstrate high values of positive animals in the techniques of IDGA and cELISA, with an almost perfect agreement between the techniques.

Besides, animals acquired among producers in the studied Mesoregion are more likely to be positive, which highlights the importance of good practices in animal transit to help control the spread of BTV.

Acknowledgments.- To "Fundação de Amparo à Pesquisa do Estado de Minas Gerais” (FAPEMIG) for financial assistance (Process: APQ - 00367-13) and scientific initiation grants, "Coordenação de Aperfeiçoamento de Pessoal de Nível Superior" (CAPES) for the master's scholarship and "Conselho Nacional de Desenvolvimento Científico e Tecnológico" (CNPq) for the scientific initiation scholarship. To the team at the Animal Virology Research Laboratory of the "Departamento de Medicina Veterinária Preventiva" at UFMG and the team at the Bovine Virus Laboratory at the "Instituto Biológico de São Paulo" for their technical support in carrying out the IDGA and Celisa tests.

\section{REFERENCES}

Abreu V.L. 1982. Prevalência de bovídeos reagentes à prova de imunodifusão para a língua azul na região norte do Brasil. Master's Thesis, Escola de Veterinária, Universidade Federal de Minas Gerais, Belo Horizonte. 45p.

Alves F.A.L., Alves C.J., Azevedo S.S., Silva W.W., Silva M.L.C.R., Lobato Z.I.P. \& Clementino I.J. 2009. Soroprevalência e fatores de risco para a língua azul em carneiros das mesorregiões do Sertão e da Borborema, semi-árido do Estado da Paraíba, Brasil. Ciência Rural 39(2):484-489. <http://dx.doi. org/10.1590/S0103-84782008005000066>

Costa J.R.R., Lobato Z.I.P., Herrnann G.P., Leite R.C. \& Haddad, J.P.A. 2006. Prevalência de anticorpos contra o vírus da língua azul em bovinos e ovinos do sudoeste e sudeste do Rio Grande do Sul. Arq. Bras. Med. Vet. Zootec. 58(2):273-275. <http://dx.doi.org/10.1590/S0102-09352006000200017>

Dorneles M.S., Morcatti F.C., Guimarães A.S., Lobato Z.I.P., Lage A.P., Gonçalves V.S.P., Gouveia A.M.G. \& Heinemann M.B. 2012. Prevalence of bluetongue virus antibodies in sheep from Distrito Federal, Brazil. Semina, Ciênc. Agrárias 33(4):1521-1524. <http://dx.doi.org/10.5433/1679-0359.2012v33n4p1521>

Konrad P.A., Rodrigues R.O., Chagas A.C.P., Paz G.F. \& Leite R.C. 2003. Anticorpos contra o vírus da Língua Azul em bovinos leiteiros de Minas Gerais e associações com problemas reprodutivos. Revta FZVA 10(1):117-123.

Laender J. 2002. Língua azul em rebanhos de ovinos e caprinos em três mesorregiões de Minas Gerais: Análise da evidência clínica e sorológica e identificação de Culicoides spp. Master's Thesis, Escola de Veterinária, Universidade Federal de Minas Gerais, Belo Horizonte. 92p.

Lima P.A., Utiumi K.U., Nakagaki K.Y.R., Biihrer D.A., Albuquerque A.S., Souza F.R., Matos A.C.D, Lobato Z.I.P., Driemeier D., Peconick A.P., Varaschin M.S. \& Raymundo D.L. 2016. Diagnoses of ovine infection by the serotype-4 bluetongue virus on Minas Gerais, Brazil. Acta Scient. Vet. 44(supl.1):1-5.

Lobato Z.I.P., Barcelos M.A.C., Lima F., Ribeiro E.B.T., Yonori E.H. \& Gouveia A.M.G. 2001. Língua Azul em ovinos e caprinos na Região Mineira da SUDENE. Anais do Congresso Brasileiro de Buiatria, Campo Grande, MS, p.165. (Resumo)

Maclachlan N.J. 2011. Bluetongue: history, global epidemiology, and pathogenesis. Prev. Vet. Med. 102(2):107-111.<http://dx.doi.org/10.1016/j. prevetmed.2011.04.005><PMid:21570141>

Melo C.B., Oliveira A.M., Azevedo E.O. Lobato Z.I.P. \& Leite R.C. 2000. Anticorpos contra o vírus da língua azul em bovinos do sertão da Paraíba. Arq. Bras. Med. Vet. Zootec. 52(1):19-20. <http://dx.doi.org/10.1590/ S0102-09352000000100004>

Nogueira A.H.C. 2008. Prevalência da Língua Azul em ovinos da região de Araçatuba, São Paulo, Brasil. Master's Thesis, Faculdade de Odontologia, Universidade Estadual Paulista, Araçatuba. 60p. 
OIE 2018. Bluetongue (infection with bluetongue virus), p.338-354. In: Ibid. (Ed.), Manual of Diagnostic Tests and Vaccines for Terrestria Animals 2018. World Organisation for Animal Health, Paris.

Ruiz-Fons F., Sánchez-Matamoros A., Gortázar C. \& Sánchez-Vizcaíno J.M. 2014. The role of wildlife in bluetongue virus maintenance in Europe: Lessons learned after the natural infection in Spain. Virus Res. 182:50-58. <http://dx.doi.org/10.1016/j.virusres.2013.12.031><PMid:24394295>

Sánchez-Cordón P.J., Perez de Diego A.C., Gomez-Villamandos J.C., SanchezVizcaino J.M., Pleguezuelos F.J., Garfia B., Del Carmen P. \& Pedrera M. 2013. Comparative study of clinical courses, gross lesions, acute phase response and coagulation disorders in sheep inoculated with bluetongue virus serotype 1 and 8. Vet. Microbiol. 166(1/2):184-194. <http://dx.doi. org/10.1016/j.vetmic.2013.05.032><PMid:23849094>

Silva M.X. 2002. Soroprevalência da Língua Azul em caprinos e sua associação com indicadores de tecnologia em propriedades no Ceará. Master's
Thesis, Escola de Veterinária, Universidade Federal de Minas Gerais, Belo Horizonte. 83p.

Souza T.S., Costa P.M., Martinez A.O., Costa Neto A.O. \& Pinheiro R.R. 2010. Anticorpos contra o vírus da língua azul em rebanhos ovinos da Microrregião de Juazeiro, Bahia. Arqs Inst. Biológico, São Paulo, 77(3):419-427.

Thrusfield M. 2004. Epidemiologia Veterinária. $2^{\text {a }}$ ed. São Paulo, Roca. 558p.

Tomich R.G.P., Nogueira M.F., Lacerda A.C.R., Campos F.S., Tomas W.M., Herrera H.M., Lima-Borges P.A., Pellegrin A.O., Lobato Z.I.P., Silva R.A.M.S., Pellegrin L.A. \& Barbosa-Stancioli E.F. 2009. Sorologia para o vírus da língua azul em bovinos de corte, ovinos e cervos campeiros no pantanal sul-matogrossense. Arq. Bras. Med. Vet. Zootec. 61(5):1222-1226. <http://dx.doi. org/10.1590/S0102-09352009000500028>

Venditti L.L.R. 2009. Infecção pelo vírus da língua azul em bovinos na região Sudeste do Brasil. Master's Thesis, Instituto Biológico, São Paulo. 77p. 